\title{
ATTITUDES OF CZECHS TOWARDS SPAS DURING THE COVID-19 PANDEMIC
}

\author{
[Postoje Čechů k lázeňství během pandemie onemocnění covid-19]
}

\author{
Petr Janeček ${ }^{1}$, Dagmar Jakubíková ${ }^{2}$ \\ ${ }^{I}$ Západočeská univerzita v Plzni, Fakulta ekonomická, Univerzitní 22, 30100 Plzen̆ \\ Email: janecp00@kmo.zcu.cz. \\ ${ }^{2}$ Západočeská univerzita v Plzni, Fakulta ekonomická, Univerzitní 22, 30100 Plzeň \\ Email: jakubikova@kmo.zcu.cz
}

\begin{abstract}
The spa industry is historically a very important part of the Czech economy. It is very deeply connected to a healthy system, but also to the tourism industry. No matter where the spa is included, it needs to be seen as a very important part of the region. There are many changes in the spa industry during the COVID-19 pandemic. Most of the spas were very deeply influenced by economic problems connected to the pandemic. Customers' opinions and attitudes were also changed. Paper deals with the opinion of Czechs on spa in connection to pandemic COVID-19. Presented results come from socio-economic research conducted on 1012 Czech respondents aged 18+. The goals of the research are to gain the opinions of Czechs on spas; their willingness to visit them; and to gain the impact of pandemic COVID-19 on their willingness to stay in the spa. Czechs see spas like places for recovering from diseases and places for old people. $16 \%$ of respondents see spas as an ideal method for recovering from COVID-19 diseas. Spa looks like quite expensive product. Spa industry need to work on its image as a product for all - for the sick and the healthy people.
\end{abstract}

Keywords: customer attitudes, pandemic COVID-19, spa, spa perception.

JEL classification: L83, M31

Received: 22.6.2021; Reviewed: 19.7.2021; 11.9.2021; Accepted: 3.11.2021

\section{Úvod}

Současná pandemická situace změnila od základu mnoho zaběhlých procesů $\mathrm{v}$ podnikatelské praxi. V cestovním ruchu a lázeňství tomu není jinak. Tyto obory poměrně úzce vázané na setkávání lidí jak z Česka, tak i ze zahraničí, byly silně ovlivněny vládními restrikcemi a obavami z nákazy onemocněním COVID-19. Lázeňství zažívá kvůli pandemii Covid-19 jedno z nejtěžších období za celou dobu své existence. V reakci na nepř́iznivý vývoj prostředí lázeňské podniky realizovaly ve svých provozech mnoho změn. Vláda a veřejná správa se snažily různou měrou podnikatelům pomoci. Nicméně názor lidí na využití služeb lázeňských zařízení se změnil. Strach, podnícený nejrůznějšími zprávami z různých zdrojů, včetně zpráv z médií a chaoticky vyložené informace, změnil ochotu potenciálních hostů do lázní príijet. Př́spěvek se zabývá názory Čechů na lázně se zaměřením na změny v období pandemie COVID-19. Př́spěvek také monitoruje některé dopady pandemie na lázeňské podniky, které byly vyvolány hygienickými opatřeními či restrikcemi vlády. Součástí výzkumu je i vliv mediálních zpráv na postoje široké veřejnosti k lázeňství.

\section{Literární rešerše}

Ozdravný účinek lázní a jejich prrírodních lečivých zdrojů je znám již dlouho. Jejich využívání má tradici především $\mathrm{v}$ evropském prostoru. $\mathrm{V}$ mnoha současných zdravotních systémech evropských států je i lázeňství součástí nebo doplňkem zdravotnického systému. V zahraničí je znatelný odklon od tradičního lázeňství k modernímu wellness pobytu s volnějším programem již několik let. (Dryglas 2020) Problémy v rozdílných podmínkách podnikání jsou mezi lázeňskými domy a wellness hotely znatelné a zástupci tradičních lázeňských procedur 
stále dbají na vysoký standard jejich služeb. V současnosti se stává tradiční lázeňská péče opět důležitým tématem, které je diskutováno jak v odborných, tak i laických kruzích. Lidé se v současné době začínají opět zajímat více o své zdraví, jak ve smyslu prevence, tak i doléčení či rekonvalescence v lázeňských zařízeních. (Pu, Du, Zhang \& Qiu 2021) Na př́kladu slovenské poptávky po lázeňských službách lze toto tvrzení potvrdit. Derco (2020) zjistil, že ve slovenských lázních roste zastoupení domácích klientů, kteří si hradí pobyt v lázních sami. Poměr slovenských samoplátců překonal i počty pacientů s příspěvkem od pojišt'oven. Dále do slovenských lázní jezdí zahraniční klientela (převážně česká, německá, izraelská, polská, ruská a rakouská). Lázeňské společnosti v současnosti nabízejí již celou řadu atraktivních produktů, které kombinují jak lázeňské, tak i wellness procedury tak, aby lázně nepůsobily jako nedostupné a luxusní produkty. (Thorne 2021) Cenovou citlivost poptávky po lázeňských službách potvrzují i Strack a Raffay-Danyi (2020). Potíže v provozu lázní posledních let před pandemií byly řešeny zavedením wellness do lázeňských míst, čímž došlo k přiblížení lázeňské a wellness péče zákazníkům. Koncept wellness je často začleněn i v mad'arských lázních, kde prováděli výzkum poptávky Strack a Raffay-Danyi (2020). K uchování léčebné tradice lázní v Česku zůstává nadále potřeba zvýšení atraktivity lázeňské nabídky, podpory ve vzdělávacím systému, marketingové a finanční podpory státu a řádného výzkumu balneologie. (Becková \& Kantorová 2021) V době krize způsobené různými př́činami, např. onemocněním COVID-19, je potřeba $\mathrm{v}$ oblasti lázeňství přehodnotit business modely lázeňských podniků. Szromek (2021) provedl výzkum u 19 největších lázeňských společností v Polsku a zjistil, že změnou produktového portfolia na léčení postcovidových symptomů a dalších obtíží s pandemií spojených (vakcinace, organizovaná izolace, léčení nemoci), dokázaly tyto podniky vytvořit udržitelný koncept podnikání i za doby krize.

Lázeňství je považováno za rodinné stř́bro České republiky i přesto, že tradiční lázeňství se dostává již několik let pod tlak moderního pojmu wellness. (Jakubíková, Vildová, Janeček \& Tlučhoř 2019) Zajímavá je i struktura obchodních společností v České republice, které provozují lázně. Velká část lázeňských podniků je vedena jako akciová společnost (44 \%), 32 $\%$ jsou společnosti s ručením omezeným, $14 \%$ jsou př́spěvkové organizace, $6 \%$ společností je v soukromém vlastnictví jednotlivců a $4 \%$ provozoven je vlastněno státem (Kraftová, Sobotková \& Sobotka 2020).

V poslední dekádě dochází k nedocenění lázeňství a jeho významu pro ekonomické a sociální prostředí. Od snižování investic, přes nedostatek personálu a nižší výkonnost marketingového řízení až po pomalou adaptaci na současné změny. Např́iklad nedostatečnou datovou základnu pro lepší práci managementu lázní, strategické plánování oboru a obhájení jeho důležitosti má za cíl odstranit Institut lázeňství a balneologie v.v.i. Institut lázeňství a balneologie je veřejná výzkumná instituce zrrízená v roce 2019 Karlovarským krajem. Cílem instituce je obnovit v České republice výzkum v oblasti lázeňství a balneologie. Výzkumné projekty se soustředí zejména na zkoumání objektivních účinků lázeňské léčby na lidský organismus a výzkum př́rodních léčivých zdrojů. Institut navazuje spolupráci s lázeňskými lékaři i $\mathrm{s}$ dalšími výzkumnými organizacemi v České republice. Nejbližšími partnery jsou Karlovarský kraj, Karlovarská agentura rozvoje podnikání, Karlovy Vary, Sdružení lázeňských míst, Svaz léčebných lázní ČR, Sdružení léčebných lázní. Zabývá se vzděláváním a spolupracuje také s vysokými školami. Vzdělávací aktivity institutu se orientují na celoživotní vzdělávání lékařů, vedení bakalářských prací, ale i na propagaci lázeňství pro laickou veřejnost. Institut také začíná pracovat na vytvoření systému certifikace lázeňských zařízení, který by do budoucna pomohl zpřehlednit situaci $\mathrm{v}$ této oblasti. $\mathrm{V}$ neposlední řadě se snaží zapojit do oblasti regionálního rozvoje a posílení oblasti výzkumu a inovací v Karlovarském kraji. (i-lab.cz 2021) 


\section{Současná situace v českých lázních}

Krize spojená s pandemií nemoci COVID-19 se v lázních výrazně projevila. Kvůli vládním opatřením zamezujícím šíření nemoci došlo v lázních $\mathrm{k}$ velkému poklesu výkonů, a to nejen z důvodu již snížené poptávky po pobytech v lázních z obavy klientů o své zdraví. Významný dopad na oblast lázeňství měly restrikce v oblasti cestování. Lázně v Česku byly v době před pandemií COVID-19 velmi navštěvovány zahraničními návštěvníky. Historicky byly vždy lázně centrem turismu, jak domácího, tak také zahraničního. Výpadek domácích a zejména zahraničních klientů se významně podepsal i na celkových výkonech lázeňství a lázeňském turismu (Boleloucka \&Wright 2020). Od 19. března 2020 platil první zákaz př́ijmu nových pacienti̊ za účelem poskytování lázeňské léčebné rehabilitační péče. (Vojtěch 2020a) V dubnu (od 27. 4. 2020) bylo březnové nařízení rozvolněno na omezený provoz pro ubytování, stravování a léčení pouze pacientů za účelem poskytnutí lázeňské léčebné rehabilitační péče $\mathrm{s}$ početnými př́snými omezeními. (Vojtěch 2020b) V květnu došlo k provoznímu uvolnění některých podmínek v oblasti stravování a poskytování léčebných procedur. (Vojtěch 2020c) Toto opatření bylo zrušeno v červnu 2020, kdy bylo možné poskytovat plně lázeňskou péči. (MZČR 2020) Na konci června zadala Vláda ČR ministryni pro místní rozvoj úkol, připravit dotační titul na podporu lázeňského cestovního ruchu - COVID-Lázně. (Babiš 2020) Od října 2020 byl provoz lázní omezen pouze na léčení pacientů s pobytem hrazeným zdravotními pojišt'ovnami. V dubnu směly lázně přijímat pacienty na rehabilitační a léčebnou péči, alespoň částečně hrazenou zdravotními pojišt'ovnami. Samoplátce přijímat nemohly. $Z$ toho důvodu měly lázeňské domy, např. v Mariánských lázních většinou obsazenost 8-10 \%. Do lázní přijížděli lidé po těžkém průběhu nemoci COVID-19, ale pouze na „předpis“, což se zdá být vůči lázeňským zařízením, jako zdravotnickým zařízením, diskriminační. (Vitásková 2021) Dalším problémem bylo, a stále ještě je, samotné vystavování návrhů na lázeňskou léčbu ošetřujícími lékaři. Ti často pracovali na dálku po telefonu a nevystavovali návrhy na pobyty v lázních, jako v době před pandemií COVID-19. (Kraftová, Sobotková \& Sobotka 2020) Zmenšil se také počet dalších zdravotních zákroků, na které navazovala péče a rekonvalescence v lázních, z důvodu přednostního řešení případů nákazy virem COVID-19.

Podpora lázeňství byla $\mathrm{z}$ pohledu vlády ČR řešena prostřednictvím lázeňských voucherů, které měly finančně zpř́stupnit lázeňský pobyt v roce 2020 a 2021. Tento krok byl sice lidmi, potenciálními klienty lázeňských zařízení, pozitivně hodnocen, ale nebyl mnohdy využit, z důvodu nejasného vysvětlení postupu uplatnění voucheru. Poskytovatelé lázeňské péče či její zprostředkovatelé hodnotili vouchery taktéž negativně. (ČT24 2021)

Lázně se snažily reagovat na pandemickou situaci a připravovaly nové produkty. Např. v Lázních Teplicích v Čechách byly nabízeny produkty pro lidi na home office nebo postcovidovou léčbu. Problémem však bylo to, že na tyto programy nemohli do lázní jezdit samoplátci, a problémy po prodělané nemoci covid byly léčeny pouze $\mathrm{v}$ rámci indikační skupiny 5 - nemoci dýchacího ústrojí (např. stavy po operaci horních cest dýchacích a dolních cest dýchacích; poškození hrtanu a hlasivek v důsledku hlasového přetížení; stavy po komplikovaném zánětu plic; bronchiektazie a další záněty dýchacího ústrojí; astma bronchiale; intersticiální plicní fibrózy; následky toxických účinků látek na dýchací cesty). (Vitásková 2021; Léčebné lázně 2021) Stejně se přizpůsobila novým podmínkám i další lázeňská místa, např. Třeboň, Luhačovice, Jáchymov nebo Františkovy Lázně. (ČTK 2021; Davidová 2021) Od března 2021 sílí i tlaky na změnu indikačního seznamu a zařazení tzv. postcovidového syndromu mezi nemoci léčené s příspěvkem zdravotních pojištoven.

Lázní se jako zdravotnických zařízení netýkalo rozvolnění opatření v létě 2020. Roušky se v prostorách resortů nosily celoročně. Lůžka musela být od sebe vzdálena minimálně dva 
metry. Klientům i zaměstnancům se pravidelně měřila teplota a skupinové procedury byly zrušeny. I na začátku roku (únor 2021) se léčilo pouze individuálně. (Dolejš 2021)

Pobyty pro lázeňské hosty byly kvůli protiepidemickým opatřením omezeny pro všechny typy zákazníků. Od ledna 2021 se mohli do lázní vrátit lidé s doporučením od lékaře. Od 1. 3. 2021, lázeňská zařízení nesměla přijímat samoplátce. Tento tah vlády hodnotí provozovatelé lázní jako protiústavní, protože znevýhodňuje hosty, kteří si chtějí za léčení zaplatit. $\mathrm{V}$ důsledku těchto restrikcí došlo např. v lázních Libverda k poklesu návštěvnosti o $60 \% \mathrm{a} \mathrm{v}$ lázních Kundratice dokonce o $90 \%$. (Švecová 2021) Od května 2021 byl povolen v lázních pobyt samoplátcům, pod podmínkou postinfekční imunity (lidé po prodělaném onemocnění COVID-19 nejdéle do 90 dnů), a plně očkovaným klientům (nejdříve dva týdny po podání poslední dávky očkování (zdravezpravy.cz 2021).

Dalším problémem, který měl na některá lázeňská zařízení silný negativní ekonomický dopad, byla ta skutečnost, že finanční prostředky (dotace) na zaměstnance a na jiné náklady mohly čerpat pouze ty podniky, které byly vládními opatřeními uzavřeny, což lázně dlouhodobě nebyly. Ty, aby snížily náklady, byly nuceny své zaměstnance nechat doma, nebo je nechat „rotovat", př́ípadně lázeňské domy zcela uzavřely. K silnému ekonomickému propadu v hospodaření lázní přispěla i uzavírka okresů, a tím výrazné omezení pohybu lidí. Lidé proto přesouvali své pobyty v lázních a vyčkávali, co se bude dít dále. (Dolanská 2021)

\section{Metodika}

Př́spěvek si klade za cíl zjistit postoje Čechů k lázeňství a zároveň ilustrovat situaci v lázeňství podle aktuálních informací z médií, které mohou významně ovlivňovat názory na lázně. Jedná se o první vstupní analýzu výsledků dotazníkového šetření, které bude součástí většího systematického sledování postojů Čechů $\mathrm{k}$ lázeňství. Dopady pandemie jsou analyzovány podrobně ve vztahu k cestovnímu ruchu a ekonomice obecně, ale na sektor lázeňství není doposud zaměřeno mnoho studií. $Z$ toho důvodu byl již v prosinci 2020 proveden výzkum mezi Čechy zaměřený na jejich postoje a vnímání lázní a lázeňství. Výzkum byl připraven ve spolupráci pracovníků Institutu lázeňství a balneologie v.v.i, Ekonomické fakulty Jihočeské univerzity v Českých Budějovicích a Fakulty ekonomické Západočeské univerzity v Plzni. Výzkum byl realizován agenturou FOCUS, Marketing \& Social Research na panelu respondentů. Za hlavní výzkumnou otázku, která koresponduje s tématem tohoto článku, si autoři zvolili: Jaký je postoj Čechů $k$ lázeňství ve spojení s onemocněním COVID-19? Dílčí otázky v šetření se týkaly bezpečnosti v lázních, názoru na rekonvalescenci po prodělání onemocnění COVID-19 a ovlivnění názoru Čechů mediálními zprávami.

Ze studia literatury a diskuze s provozovateli lázeňských zařízení vyplynuly předpoklady pro výzkum, které budou vyhodnoceny na základě četností odpovědí respondentů.

Předpoklad 1: Lázně jsou vnímány jako místo pro staré nebo nemocné lidi.

Předpoklad 2: Vnímání lázní Čechy se změnilo $\mathrm{v}$ důsledku mediálních zpráv $\mathrm{s}$ tématem pandemie COVID-19.

Výzkum byl realizován formou dotazníkového šetření. Výběrový vzorek respondentů reprezentoval populaci v České republice ve věku 18 a více let. Výzkum probíhal on-line dotazováním - metodou CAWI na panelu respondentů. Kvótní výběr byl nastaven dle pohlaví, věku, vzdělání, velikosti místa bydliště a kraje. Dotazovací nástroj byl sestaven výzkumným týmem na základě konzultace s profesními organizacemi a zástupci lázeňských 
léčeben. Srozumitelnost dotazníku byla testována na pilotním vzorku 30 osob. Dotazník obsahoval 18 otázek o lázeňství a 7 sociodemografických otázek. Tento příspěvek se zabývá především otázkami spojenými s pandemií COVID-19 a lázeňstvím.

Sběr dat probíhal od 4. 12. do 12. 12. 2020. Vyplnění dotazníku probíhalo on-line a respondentům trvalo přibližně 10 minut. Data byla zpracována v softwaru MS Excel, SPSS a Power BI. Podrobné výsledky jsou prezentovány také na webu www.spadata.cz.

\section{Výsledky výzkumu}

Celkem bylo sebráno 1012 vyplněných dotazníků od Čechů ve věkovém složení reprezentující populaci České republiky. Nejmenší zastoupení měli respondenti z věkové kategorie 18-24 let (9\%), $16 \%$ osob bylo ve věku 25-34 let. Další věková kategorie 35-44 let byla zastoupena $21 \%$. Podíl $17 \%$ měli lidé ve věku 45-54 let a $37 \%$ tvořili lidé ve věku 55 let a více. $Z$ pohledu genderového rozložení dotazovaných je poměr vyvážený, tedy $51 \%$ mužů a 49 \% žen. Základního vzdělání dosáhlo $11 \%$ respondentů. Středoškolského vzdělání dosáhlo celkem $70 \%$ respondentů, z čehož $35 \%$ respondentů odmaturovalo. Vysokoškolské vzdělání mělo $19 \%$ respondentů.

Velká část respondentů $(72 \%)$ v lázních nebyla ani jednou za posledních 10 let. Zájem o pobyt v lázních projevilo ve výzkumu $65 \%$ respondentů. Důvody proč do lázní nejet zobrazuje obrázek č. 1.

Obrázek 1: Bariéry v uvažování o pobytu v lázních, $n=972$

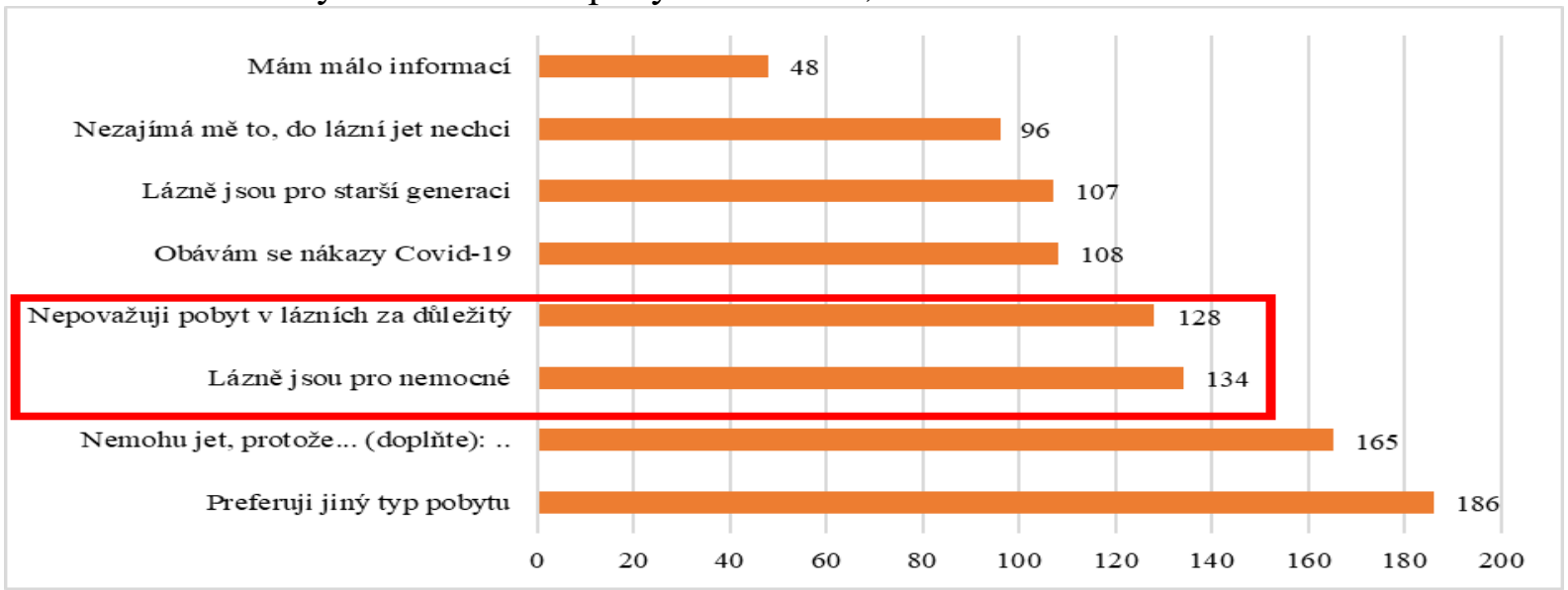

Zdroj: Vlastní výzkum, 2020

Nejčastější důvody jsou preference jiného typu pobytu a bariéry, které neumožňují vycestovat (např. péče o domácnost, blízké apod.). Další časté důvody vychází ze zažité image lázní jako místa pro nemocné a dále s poměrně velkým počtem odpovědí také místa pro starší generace. Problematická je také vysoká četnost odpovědi: „nepovažuji pobyt v lázních za důležitý“. Je zde znatelné, že tito respondenti nepřikládají lázním význam preventivní, ale spíše následné zdravotní péče. 108 respondenti̊ se obávalo nákazy onemocnění COVID-19, 96 respondenti̊ se o lázně nezajímá a 48 respondentů nemá dostatek informací, aby do lázní odjeli.

Motivy pro cestu do lázní byly spojeny s finančními pobídkami (at' už přímo finančním příspěvkem na pobyt, rozšíření nabídky pobytů hrazených pojišt'ovnami), tak i přístupem praktických lékařů při předepisování lázní. Dále to byl z 27 \% špatný zdravotní stav, což je opět propojené s vnímáním lázní, jako místa, kde se následně řeší zdravotní problémy, nikoliv se jim předchází. 
Tabulka 1: Kritéria výběru lázní, $n=1012$

\begin{tabular}{|c|c|}
\hline Před pandemií COVID-19 & V době pandemie COVID-19 \\
\hline 1. Cenová dostupnost lokality & 1. Cenová dostupnost lokality \\
\hline 2. Př́roda v okolí & 2. Př́roda v okolí \\
\hline 3. Dostupnost lokality & 3. Bezpečnost místa \\
\hline 4. Doporučení přátel & 4. Dostupnost lokality \\
\hline 5. Věhlas místa & 5. Doporučení přátel \\
\hline $\begin{array}{l}\text { 6. Nabídka kulturního a sportovního } \\
\text { vyžití v destinaci }\end{array}$ & 6. Věhlas místa \\
\hline 7. Bezpečnost místa & 7. Nabídka kulturního a sportovního vyžití v destinaci \\
\hline 8. Podle recenze (např. Tripadvisor) & 8. Podle recenze (např. Tripadvisor) \\
\hline
\end{tabular}

Zdroj: Vlastní výzkum, 2020

Kritéria výběru lázeňské destinace se před a během pandemie onemocnění COVID-19 změnila. Respondenti mohli seřadit kritéria podle důležitosti $\mathrm{v}$ době před pandemií a $\mathrm{v}$ době pandemie COVID-19. Před pandemií, ale i během ní zůstává nejdůležitějším kritériem cenová dostupnost lokality a prrírodní prostředí. Kritérium bezpečnost místa se během pandemie změnilo. Posunulo se v důležitosti ze 7 . na 3. místo.

Z výše uvedených výsledků, lze usuzovat, že lázně jsou vnímány jako dražší typ pobytu, který využívají především lidé movití nebo lidé s možností prííspěvku na pobyt.

Obrázek 2: Způsob ideální rekonvalescence po nemoci COVID-19, n = 1012
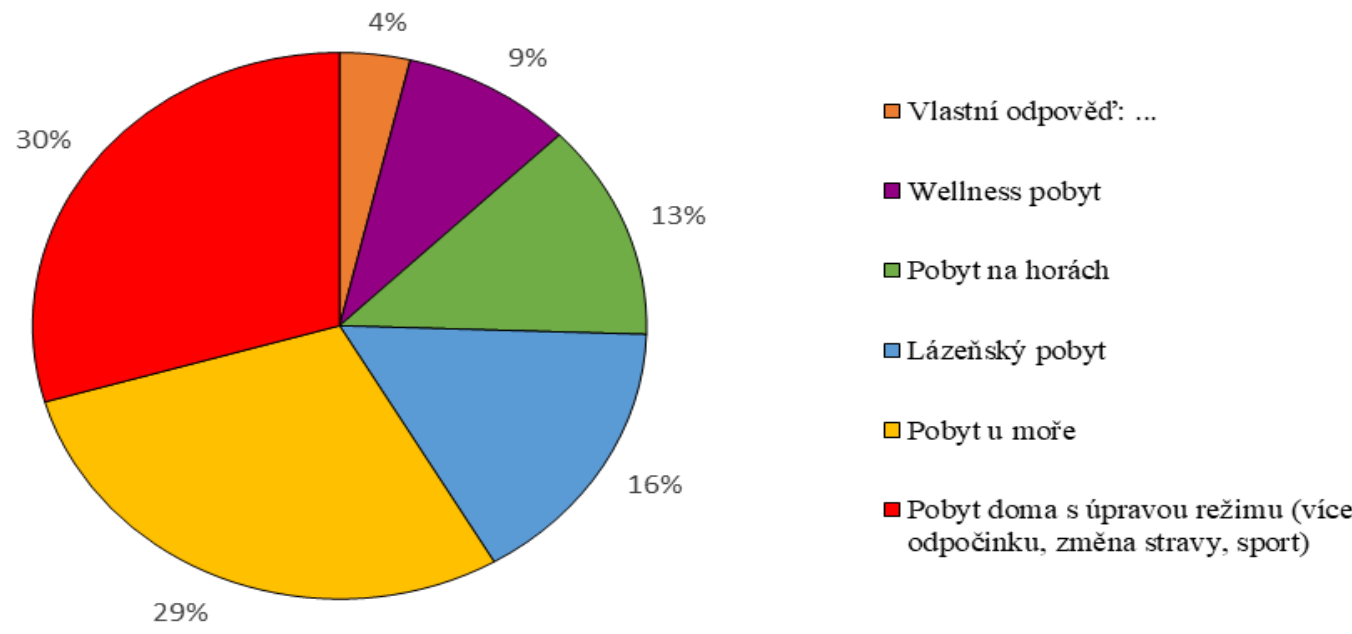

Zdroj: Vlastní výzkum, 2020

Při dotazování na to, jaký je nejlepší způsob rekonvalescence po prodělání onemocnění COVID-19 respondenti nejčastěji uváděli pobyt doma $\mathrm{s}$ úpravou režimu (více odpočinku, změna stravy a sport) a pobyt u moře (obě téměř $30 \%$ odpovědí). Je potřeba vzít v úvahu, že v době dotazování byl upraven pohyb lidí do zahraničí a pobyt u moře mohl být preferován z tohoto důvodu více. Dále zmiňovali pobyt $\mathrm{v}$ lázních, který byl zastoupen $16 \%$. Pokud vezmeme $\mathrm{v}$ potaz $\mathrm{i}$ to, že se $\mathrm{v}$ lázních často poskytují i wellness pobyty, tak se jedná o čtvrtinový podíl odpovědí. Je potřeba zmínit, že výzkum probíhal v prosinci 2020 , kdy nabídky postcovidové léčby ještě nebyly tak běžné a lidé neměli dostatek informací, jak se po nemoci zotavit, ale i přesto jsou lázně a ozdravné pobyty vnímány pozitivně. Dle literární rešerše i lázeňské podniky dobře zareagovaly a nabídly nové produkty pro rekonvalescenci po onemocnění. 
Obrázek 3: Informace o provozu lázní, $\mathrm{n}=1050$

Ano, znám osobně někoho, kdo byl letos v lázních

Ano, sám/sama jsem byl/a letos v lázních

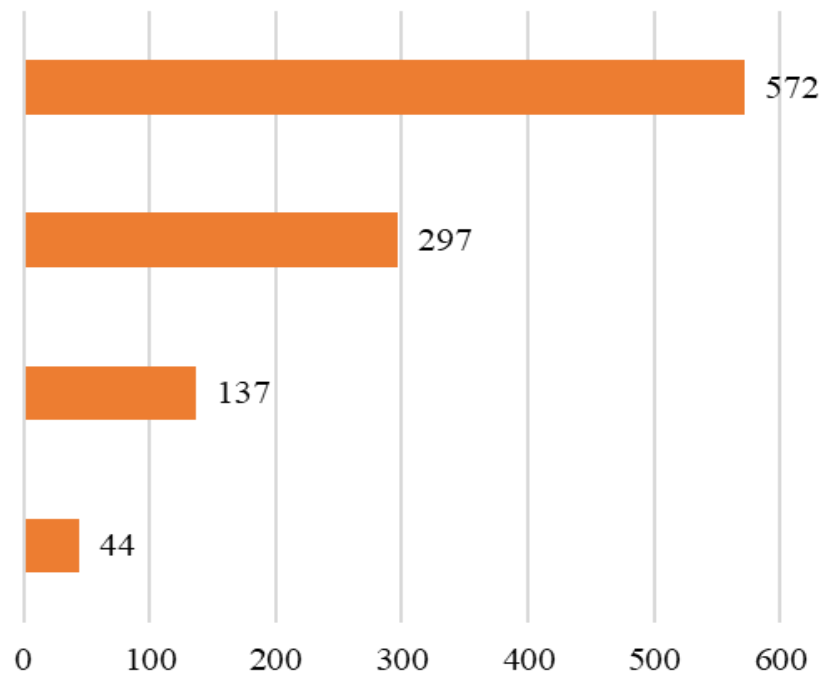

Zdroj: Vlastní výzkum, 2020

Z obrázku č. 3 vyplývá, že mnoho respondentů se o lázně vůbec nezajímá, a proto informace o nich nevyhledávají. Ti, co se o lázně zajímají, mají informace především z médií nebo od lidí, kteří v lázních již byli. Výzkum nebyl zaměřen na zjištění kvality informací, ale pouze na jejich existenci. Není tedy možné zjistit, zda informace o provozu lázní byly pravdivé a aktuální.

Na dalším obrázku č. 4. jsou odpovědi na otázku "Jak ovlivnily Váš postoj k návštěvě lázní informace z médii o výskytu COVID-19 v některých lázeňských městech a jejich okoli??" $61 \%$ respondentů uvedlo, že se jich to netýká, protože pobyt v lázních neplánovali. Tyto odpovědi byly odstraněny. $\mathrm{V}$ grafu jsou tak pouze odpovědi respondentů, na které média působila (tedy 394 z celkového 1012).

Obrázek 4: Vliv médií, $\mathrm{n}=394$

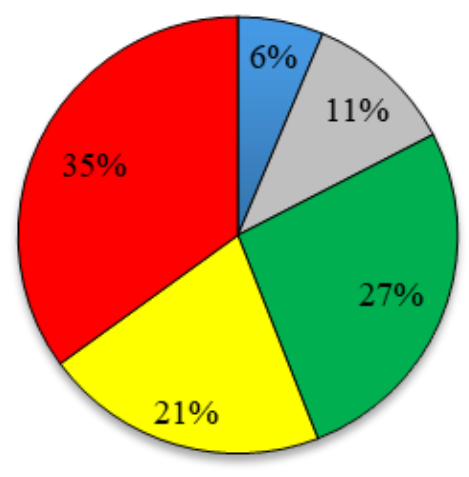

$\square$ Mám obavy, ale protože mám pobyt hrazený pojištovnou, pojedu

$\square$ Mám obavy, ale přesto pojedu i jako samoplátce

$\square$ Nemám obavy, pojedu jako samoplátce

$\square$ Nemám obavy, pojedu na pobyt hrazený pojišstovnou

$\square$ Odradilo mě to

Zdroj: Vlastní výzkum, 2020 
Největší část respondentů (35\%), kteří zvažovali návštěvu lázní, informace z médií o výskytu onemocnění COVID-19 v lázeňských městech odradily od pobytu. Celekm 59 \% respondentů nemělo obavy a do lázní by odjelo. Pouze 17 \% respondentů mělo obavy, ale i přesto by do lázní odjelo.

Pocit bezpečí v lázních zvyšují opatření, která byla bud' nařízena vládou, nebo je lázně zavedly z preventivních důvodů. Nejčastěji byl zmiňován omezený počet hostů v lázních, pravidelné testování personálu, častější kontroly a dodržování zvýšených hygienických opatření nebo povinné testy klientů lázní. Tato opatření byla v lázních zavedena a fungují do současnosti.

\section{Shrnutí a závěr}

Z výsledků výzkumu vyplynulo, že lázně si zachovávají svou image i během pandemie COVID-19, která není pro lázně dlouhodobě příznivá. Mnoho respondentů se o lázně př́liš nezajímá z toho důvodu, že si myslí, že jsou využívány jako následná zdravotní či rehabilitační péče po operačním zákroku nebo prodělané nemoci. Funkci prevence nemoci nevnímají tak silně, jak by bylo žádoucí. Byl potvrzen předpoklad 1, že lázně jsou vnímány jako místo pro starší a nemocné lidi. Lázně jsou vnímány jako dražší produkt, v některých př́ípadech možná i luxusní produkt. Ke stejnému závěru dospěl i Thorne (2021), který tento problém také zkoumal. Ten zjistil rozdíly mezi vnímáním luxusu u wellness a u lázeňství. Wellness je podle jeho výsledků chápáno jako méně luxusní statek, protože může být součástí každodenního života, zatímco $\mathrm{v}$ př́ípadě lázeňství tomu tak není. $\mathrm{V}$ našem případě bylo zkoumáno pouze lázeňství. Z otázek, které se zabývaly podporou lázeňství, je patrné, že finanční omezení je významnou bariérou pro pobyt v lázních, z čehož lze usuzovat, že se jedná o luxusnější produkt. Zajímavé bylo zjištění, že lidé toužili po finančí pomoci k pobytu v lázních, ale využívání lázeňských voucherů nebylo v praxi tak masivní, jak se očekávalo. Lidé využívali voucherů především do lázeňských míst, která patří běžně v nejdražším.

Z výše uvedeného plynou možná doporučení pro lázeňské podniky, které by měly pracovat společně s lázeňskými místy a dalšími stakeholdery na zlepšení image lázeňství jako oboru, který pomáhá nejen při zdravotních potížích, ale také působí preventivně v oblasti fyzického i psychického zdraví. Lázeňské podniky by se měly zaměřit na inovace svých podnikatelských konceptů, vyhledávat nové prŕležitosti na trhu (některé se př́ležitosti již chopily) a inovovat svou produktovou nabídku také ve vztahu k potřebám post-pandemického trhu.

Onemocnění covid nevnímali respondenti jako velkou hrozbu, pokud byli rozhodnuti do lázní jet. Zavedená hygienická opatření jim zvyšovala pocit bezpečí pobytu v lázních. Důležitým faktorem v rozhodovacím procesu, zda do lázní jet, jsou finanční náklady spojené s pobytem v lázeňském zařízení a s cestou. Podobné výsledky, jako ve zde prezentovaném výzkumu, potvrzují i Strack a Raffay-Danyi (2020) na mad'arském trhu, kde je jako hlavní rozhodovací faktor vnímána cena, dále čistota zařízení, typ bazénů a doporučení od známých. Pandemie COVID-19 změnila přístup Čechů $\mathrm{k}$ výběru lázní. V současnosti hodnotí jako druhé nejdůležitější kritérium výběru lázní bezpečnost. V kombinaci s výsledky vlivu médií na návštěvu lázní můžeme potvrdit i předpoklad 2. Větší vliv měly mediální zprávy s tématem pandemie COVID - 19 především na ty, kteří nemají s lázněmi zkušenosti nebo nebyli pro pobyt v lázních rozhodnuti. Ti, kteří jsou pravidelnými návštěvníky lázní a jsou rozhodnuti pobyt realizovat, nebyli ovlivněni nejrůznějšími informacemi ani omezeními, které lázně byly nuceny zavést. 
Pro mnohé lidi je problémem dostat se do lázní a realizovat lázeňský pobyt. Již zmíněná finanční náročnost se kombinuje s omezeními, týkající se přijímání klientů k pobytu na základě vládních opatření, která lázeňská zařízení musí dodržovat i způsob předepisování lázeňské péče. Praktičtí lékaři řeší mnoho jiných zdravotních problémů, a tak se vypisování návrhů na lázeňskou péči odsouvá na později. Podobně jsou kvůli pandemii odkládány i chirurgické a další zákroky, a tím i následná rehabilitační péče v lázeňských zařízeních.

Jako další významný problém, se kterým se lázeňství potýká, je procesně-provozní oblast, která se vypořádává $\mathrm{s}$ důsledky vládních opatření. Nemožnost př́imu samopláteckých pacientů a zdlouhavé provedení změn $\mathrm{v}$ indikačním seznamu zabraňuje hospodárnému provozu lázní. Vouchery, které byly lázeňskými podniky vnímány jako dobrý nástroj pro podporu poptávky, byly administrativně náročné. I když problematika voucherů nebyla hlavním tématem př́spěvku, výzkumem bylo zjištěno, že respondenti o ně nejevili velký zájem i přes to, že finanční stimul k pobytu by si práli. Přičinou bylo, že neměli dostatek informací o možnosti jejich využití, nebo nesplňovali kritéria pro jejich uplatnění.

Výzkum potvrdil, že lázeňství trpí ze strany poptávky nálepkou místa pro nemocné a starší lidi. Tuto image je potřeba změnit a vrátit lázním punc místa klidu, relaxace a načerpání nových sil bez ohledu na řešení vzniklého onemocnění, ale především jako preventivní způsob, jak zdravotním problémům předcházet. Na tomto úkolu se bude dozajista podílet kromě lázeňských míst a společností i Institut lázeňství a balneologie, který se bude zabývat výzkumem v lázeňství, jak po stránce socio-ekonomické, tak i balneologické a terapeutické.

Provedený výzkum má svá omezení, na která je potřeba upozornit. Jedná se o první fázi výzkumu s tímto tématem. Pro jasné argumenty vycházející $\mathrm{z}$ dat by bylo vhodnější porovnat výsledky z doby přelomu roku 2020-2021 s obdobím před a po tomto období. Některé trendy $\mathrm{v}$ postojích se mohou měnit a některé mohou přetrvávat bez ohledu na pandemii COVID-19. Výzkum je založen pouze na kvantitativním šetření, které má své nevýhody především v menší detailnosti odpovědí. Výzkum by bylo vhodné do budoucna doplnit o kvalitativní část.

\section{Poděkování}

Př́spěvek byl podpořen $\mathrm{v}$ rámci projektu SGS-2021-020 Změny v ekonomice a marketingu turismu. Poděkování patří také kolegům z Institutu lázeňství a balneologie a Jihočeské univerzity v Českých Budějovicích.

\section{Literatura}

[1] BOLELOUCKA, E. and A. WRIGHT, (2020). Spa Destiantions in the Czech Republic: an empirical evaluation. International Journal of Spa and Wellness. 3(2-3), 117-144. DOI: $10.1080 / 24721735.2021 .1880741$

[2] BABIŠ, A., (2020). Usnesení vlády České republiky č. 703. [online]. [cit 27th Septeber 2021]. Accessible from: https://apps.odok.cz/attachment/-/down/IHOABR4JGNBP

[3] BECKOVÁ, H. and K. KANTOROVÁ, 2021. Wellness as a cure for the problems of Czech spas? International Journal of Spa and Wellness. 4(1), 36-52. ISSN 2472-1735, DOI: $10.1080 / 24721735.2021 .1908077$

[4] ČT24, 2021. Mnoho lázní nepřijímá státní poukazy na pobyt. Cestovky se s nimi musí dohodnout, tvrdí ministerstvo. Česká televize, ČT24 [online]. [cit. 21st May 2021]. Accessible from: https://ct24.ceskatelevize.cz/domaci/3139127-mnoho-lazni-neprijimastatni-poukazy-na-pobyt-cestovky-se-s-nimi-musi-dohodnout-tvrdi 
[5] ČTK, 2021. Lázně v Luhačovicích a Jáchymově nabízejí doléčení po covidu. ČTK [online]. [cit. 21st May 2021]. Accessible from: https://www.ceskenoviny.cz/zpravy/lazne-v-luhacovicich-a-jachymove-nabizejidoleceni-po-covidu/1982269

[6] DAVIDOVÁ, J., 2021. Slatinné lázně Třeboň léčí pocoidové následky. Táborský deník [online]. [cit. 21st May 2021]. Accessible from: https://taborsky.denik.cz/zpravy_region/slatinne-lazne-trebon-leci-pocovidove-nasledky20210211.html

[7] DERCO, J. (2020). Spa tourism in the Slovak Republic. International Journal of Spa and Wellness. 3(2-3), 187-197. DOI: 10.1080/24721735.2020.1857206

[8] DOLANSKÁ, J., 2021. Nálepka rizikové lokality odrazuje klienty, říká šéf Svazu léčebných lázní. iDnes.cz [online]. [cit. 21st May 2021]. Accessible form: https://www.idnes.cz/karlovy-vary/zpravy/rozhovor-eduard-blaha-svaz-lecebnych-laznilazenstvi-covid.A210217_594810_vary-zpravy_ba

[9] DOLEJŠ, J., 2021. Lázně se potýkají s nedostatkem klientů. Kvůli nízké obsazenosti omezily provoz. Česká televize, ĆT24 [online]. [cit. 21st May 2021]. Accessible from: https://ct24.ceskatelevize.cz/specialy/koronavirus/3266662-lazne-se-potykaji-snedostatkem-klientu-kvuli-nizke-obsazenosti-omezily

[10] DRYGLAS, D., 2020. Wellness as a newe direction of development of Polish spa resort. Interantional Journal of Spa and Wellness. 3(2-3), 69-81. ISSN 2472-1735, DOI: https://doi.org/10.1080/24721735.2020.1857207

[11] I-LAB.CZ, 2021. O institutu. i-lab.cz [online]. [cit. 21st May 2021]. Accessible from: https://www.i-lab.cz/o-nas/

[12] JAKUBÍKOVÁ, D., E. VILDOVÁ, P. JANEČEK a J. TLUČHOŘ, 2019. Lázeňství: management a marketing. 1st ed. Praha: Grada. ISBN 978-80-271-2461-9

[13] KRAFTOVÁ, I., L. SOBOTKOVÁ and M. SOBOTKA., 2020. Is the type of owner of Czech spas reflected in their operational and financial performance? International Journal of Spa and Wellness, 3, 2-3, 100-116. ISSN 2472-1735, DOI: 10.1080/24721735.2021.1899615

[14] LÉČEBNÉ LÁZNĚ, 2021. V. Nemoci dýchacího ústrojí. Léčebné lázně [online]. [cit. 27th September 2021]. Accessible from: https://translate.google.cz/?hl=cs\&tab=rT\&sl=cs\&tl=en\&op=translate

[15] MNČR, 2020. Inforamce MZČ o vydání mimořádných opatření MZ a zrušení ochranných opatřeních vydaních ke dni 17. 6. a 19. 6. 2020 čj. 677/20. Ministerstvo zdravotnictví. [online]. [cit 27th September]. Accessible from: https://www.vlada.cz/cz/epidemie-koronaviru/dulezite-informace/vladni-usnesenisouvisejici-s-bojem-proti-epidemii-koronaviru---rok-2020-186999/\#rijen

[16] PROTIVANSKÁ, L., 2021. Po covidu do lázní? Nebojte se zeptat lékaře, radí šéf lázeňského centra. Idnes.cz [online]. [cit 21st May 2021]. Accessible from: https://www.idnes.cz/karlovy-vary/zpravy/koronavirus-covid-anticovid-balicek-laznekynzvart-lazenstvi.A210126_591239_vary-zpravy_ba

[17] PU, B., V. DU, L. ZHANG and Y. QIU, 2021. Subjective knowledge and healt consciousness influences on health tourism intention after the COVID-19 pandemic: A prospective study. Journal of Psychology in Africa. 31(2), 131-139. ISSN 1433-0237 DOI: https://doi.org/10.1080/14330237.2021.1903181 
[18] STRACK, F. and A. RAFFAY-DANYI, (2020). Well-being and healing and characteristics of demand for spas in Hungary. International Journal of Spa and Wellness, 3(2-2), 145-165. DOI: 10.1080/24721735.2021.1875614

[19] SZROMEK, A., R., (2021). Transformatin of Business Models in Spa Enterprises for Medical Purposes in Situations of Epidemic Threats. Journal of Open Innovatin. 7(143), 1-24. DOI: https://doi.org/10.3390/joitmc7020143

[20] ŠVECOVÁ, J., (2021). Samoplátci se opět můžou objednávat do lázní. Ptali jsme se v Libverdě a Kundraticích, jaký je zájem. Český rozhlas Liberec [online]. [cit. 21st May 2021]. Accessible from: https://liberec.rozhlas.cz/samoplatci-se-opet-muzou-objednavatdo-lazni-ptali-jsme-se-v-libverde-a-8456799

[21] THORNE, S., 2021. Are spas and wellness still considered luxurious in today's world? Research in Hospitality Management. 11(1), 9-14. ISSN 2224-3534 DOI: https://doi.org/10.1080/22243534.2020.1867379

[22] TRNKA, Z. a N. KRÁSNÁ, 2021. Karlovarský kraj jedná s ministerstvem zdravotnictví o možnosti otevř́t lázně pro samoplátce. Český rozhlas Karlovy Vary [online]. [cit. 21st May 2021]. Accessible from: https://vary.rozhlas.cz/karlovarsky-kraj-jedna-sministerstvem-zdravotnictvi-o-moznosti-otevrit-lazne-8469333

[23] VITÁSKOVÁ, J., 2021. Lázně nabízejí rehabilitační program pro ty, kteří prodělali onemocnění covid-19. Český rozhlas - Sever [online]. [cit. 21st May 2021]. Accessible from: https://sever.rozhlas.cz/lazne-nabizeji-rehabilitacni-program-pro-ty-kteri-prodelalionemocneni-covid-19-8455149

[24] VOJTĚCH, A., 2020a. Mimořádné opatření MZČR, Usnesení vlády č. 307. [online]. [cito 27th September 2021]. Accessible from: https://www.vlada.cz/cz/epidemiekoronaviru/dulezite-informace/vladni-usneseni-souvisejici-s-bojem-proti-epidemiikoronaviru---rok-2020-186999/\#rijen

[25] VOJTĚCH, A., 2020b. Mimořádné opatření MZČR, Usnesení vlády č. 450. [online]. [cito 27th September 2021]. Accessible from: https://www.vlada.cz/cz/epidemiekoronaviru/dulezite-informace/vladni-usneseni-souvisejici-s-bojem-proti-epidemiikoronaviru---rok-2020-186999/\#rijen

[26] VOJTĚCH, A., 2020c. Mimořádné opatření MZČR, Usnesení vlády č. 555. [online]. [cito 27th September 2021]. Accessible from: https://www.vlada.cz/cz/epidemiekoronaviru/dulezite-informace/vladni-usneseni-souvisejici-s-bojem-proti-epidemiikoronaviru---rok-2020-186999/\#rijen

[27] ZDRAVEZPRAVY.CZ, 2021. Pobyt v lázních podmiňuje platné očkování proti covidu19. Zdravezpravy.cz [online]. [cit 21st May 2021]. Accessible from: https://www.zdravezpravy.cz/2021/05/04/pobyt-v-laznich-podminuje-plne-ockovaniproti-covidu-19/ 